\title{
THE ROLE OF ZAKAT IN THE EARLY STAGES OF THE ISLAMIC CIVILISATION
}

\author{
Avazbek Ganiyev \\ International Islamic Academy of \\ Uzbekistan, Doctor of philosophy $\mathrm{PhD}$, Senior \\ lecturer \\ At the Department of the Islamic studies and \\ ICESCO Chair \\ For the study of Islamic Civilization. \\ 11, A.Kadiri, Tashkent, 100011, Uzbekistan.
}

\author{
Sherzodjon Umaraliev \\ International Islamic Academy of \\ Uzbekistan, lecturer at the Department of the \\ Islamic studies \\ and ICESCO Chair For the study of Islamic \\ Civilization \\ 11, A.Kadiri, Tashkent, 100011, Uzbekistan.
}

Article DOI: https://doi.org/10.36713/epra2823

\begin{abstract}
"Zakat" is one of the five pillars of Islam. It is also stated that it is one of the main components in Islamic finance. Its aim is to balance wealth distribution in the country fairly. Zakat is interpreted as almsgivings to the poor and the "needy" and for payers; it is the purification of their souls through helping the needy and a way of restraining from greed and arrogance. Legally, "Zakat means the transfer of ownership of specific wealth to the specific individual or individuals under the specific conditions" $"$. This article discusses early zakat developments and it is divided into 1. introduction 2. The Law of Zakat during the lifetime of the Prophet (S.A.W.) 2. Zakat practices during the period of the Khulafah Al-Rashdin.
\end{abstract}

\footnotetext{
${ }^{1}$ Ganiyev, Avazbek () "INSTITUTION OF ZAKAT IN COLONIAL MALAYSIA," The Light of Islam: Vol. 2020 : Iss. 1 , Article 2. See P.10
} 


\section{INTRODUCTION}

With the birth of Islam at the heart of today's Saudi Arabia, Makkah, zakat was revealed in the ayah and surat of the Qur'an during the Prophet's 23 years' mission in Makkah and Madinah. Powell writes, "The revelations from Makkah established general principles of stewardship and charity, and the passages of the Madinah transformed these principles into rules that applied within the Muslim polity."2 During the Makkah revelations, Muhammad (S.A.W.) received Surah al-Duha, al-Muddaththir, al-Ma'arij and alMaryam pertaining the zakat. As Siddiqi writes,

In surah al-Duha, the Prophet is reminded that when he was an orphan God gave him shelter, when he was ignorant He showed him the right path, when he was poor, He made him rich. The Prophet has been instructed not to be hard on orphans and not to be child on the ones who ask, and to maintain in acknowledging openly the blessing of God. Similarly, in surah al Muddaththir while depicting the 'hereafter', the Qur'an states that those on the right will be in the Gardens and will ask the guilty ones about what brought them to Hellfire. These will answer then that they did not pray nor did they feed the poor and they joked and denied the Day of Judgment, now, 'we are confronted with this certain truth'.

The same message is stated in surat alDhariyat and al-Ma'arij but in much stronger terms. In both these surat there are statements as Muhamad writes, "the definite right of the needy and the deprived to a share in the property of those who are well off." 4 In surah al-Dhariyat, while describing "the heavenly blessings for the pious in the Hereafter, it is explained that they deserve these blessings on account of the fact that in their previous life they slept little at night. In the later phase of night asked for his forgiveness; further, the needy and the deprived had a haqq (share) in their wealth." ${ }^{5}$ In surah al Ma'arij where the vivid depiction of the punishment in the Hereafter is described. It is stated,

\footnotetext{
${ }^{2}$ See Powell R. (2010). Zakat: Drawing Insights for Legal Theory and Economic Policy from Islamic Jurisprudence. 7 PITT. TAX REV. 43. p. 48 ${ }^{3}$ Siddiqi M. A. S. (1983) Early Development of the Zakat Law and Ijtihad. First edition. Islamic research Academy, Karachi, Pakistan see p. 24

${ }^{4}$ Muhamad A. A. (1993). Zakat and rural development in Malaysia. Berita Publishing SDN BHD. Kuala Lumpur, Malaysia. See p. 67 ${ }^{5}$ The Qur'an, surah al Dhariyat (51:17-19)
}

The criminal will wish that he could be ransomed from the punishment of that Day by his children, his wife, brother, other relatives. Who protected him and all the people of the world to save himself, but he will not be able to escape from wrath, for there will be a flaming fire that will lick his flesh and which will call everyone who turned his back and retreated, hoarded wealth and withheld it, to itself. Only those who pray regularly and in whose wealth the needy and deprived have a haqq ma'lum (definite or recognized right) can escape this vice. ${ }^{6}$

The research suggests that, it is very important to be responsible while a person tested with wealth. In order to avoid severe punishment in hereafter, one should pay zakat, give sadaqah and pray regularly.

\section{THE LAW OF ZAKAT DURING THE LIFETIME OF THE PROPHET (S.A.W.)}

During the Madinah period, after Prophet Muhammad (S.A.W.) made Hijrah in 622 C.E., surat regarding zakat were elaborated and were detailed compared to the Makkah revelations. Practical steps were also taken to regulate and systematize the implications of the Makkah surat. ${ }^{7}$ In surah al-Hajj, we see one of the many instances in which the words "aqimu al-salah and atu al-zakat (so establish prayer and give zakat)' $\%$ were mentioned. As much as Muslim obligatory prayers were governed by the example and the practice of the Prophet (S.A.W.), he also set the fundamental principles and practices governing the implementation of zakat. During the Prophet's (S.A.W.) time, zakat was levied on almashiyah (animal properties), al- 'ayn (gold, silver and coins) and al-harth (agricultural produce). Zakat al-Fitr was also ordained during the Prophet's time. There are some reports that during that time zakat was established on honey ${ }^{9}$ and merchandise. ${ }^{10}$ The administration of the zakat as a system started during Prophet's (S.A.W.) time in Madinah, where he used to send collectors of zakat to various tribes. The zakat collectors at that time were trained and knew their roles and responsibilities. Muhamad writes that "Zakat

\footnotetext{
${ }^{6}$ The Qur'an surah al-Ma'arij (70:12-26)

${ }^{7}$ Muhamad A. A. (1993). Zakat and Rural

Development in Malaysia. Kuala Lumpur, Malaysia.

Berita Publishing. See p.36

${ }^{8}$ Surah Al-Hajj (22:78)

${ }^{9}$ Malik b. Anas, Al-Muwatta' (version of Al-

Shaybani) p. 118

${ }^{10}$ Sunan Abu Dawud, Vol. 2, p. 95
} 
as a compulsory levy supervised by the State with its whole set of rules was introduced by the prophet probably when he sent his collectors to different tribes."11 Although at that stage the items on which zakat were levied were not too many, the differentiated rates in the case of the livestock were rather complex. Because of this, the zakat collectors were particularly trained for the job. ${ }^{12}$ Even though all collectors of zakat were well trained before they were sent to different tribes to collect zakat from the rich and distribute to the poor, some were not doing their job well so a few complaints occurred. This made it necessary to put down the relevant details of the subject and send them to the officials in order to avoid grievances from the zakat-payers. Eventually, this was done. Muhamad explains, "A document was written (Kitab al-Sadaqah) and copies circulated as a basic set of rules for practice in the future. Beside these safeguards, zakat-payers were also advised to be tolerant to and cooperative with these officials."13 Zakat funds distribution was strictly confined to eight categories. The Prophet (S.A.W.) used to distribute remaining zakat and sadaqah immediately after they were brought to him by the zakat amil after their distribution in collected places. By this way, he showed that zakat should not be accumulated and must be given to the beneficiaries as soon as possible.

\section{ZAKAT PRACTICES DURING THE PERIOD OF THE KHULAFAH AL- RASHDIN}

During the time of the Prophet, there were his companions who later became Khulafah. These companions had been consistently present at the side of the Prophet, especially at the early difficult stages of his missionary struggle. Due to this fact, they were most familiar with the Prophet's (S.A.W.) position of the true Islamic vision. ${ }^{14}$ These companions and later Khulafah were Abu Bakr, 'Umar, 'Uthman and 'Ali who ruled in total for 3 decades. During their Khulafah they were not only practising zakat as enforced by the Prophet (S.A.W.) based on the injunctions of the Qur'an and his Sunnah but also they themselves according to time, place and the situation at the time made some elaborations and added details on zakat practices.

Abu Bakr's period of rule was short but very crucial as regards to zakat administration. Being the first Khalifah, Abu Bakr ordained zakat collectors to send surplus funds to the central government in Madinah. However, the character of the traditional Arab tribes came to the scene, being reluctant to obey any central government and some refused to pay any zakat. Some were still reluctant to accept Islam, while some were believers but had not accepted Islam yet and did not want to pay zakat. Thus, it was clear that the real issue with all these tribes was their nature and character being reluctant to be under one government. In the light of the repeated surat of the Qur'an "aqimu al-salah wa atu al-zakat."ls Whoever was not following the direct command of Allah (SWT) were considered as apostates. Muhamad writes that "Abu Bakr, as a ruling khalifah, was also not prepared to make any distinction between salah and zakat based on clear injunctions of the Qur'an stated above as well as the practice of the Prophet (S.A.W.). He considered zakat as not only an obligatory duty for eligible Muslims but also the duty of the government to collect and spend on those categories of people specified in the Qur'an."16

During the rule of the Khalifah 'Umar ibn al Khattab, zakat coverage was extended due to the new situation occurrences. In the beginning, Prophet (S.A.W.) exempted horses from the zakat in the light of the horse only used for work and transportation purposes. However, during the rule of the Khalifah 'Umar, Syria and Palestine were conquered. Horses in these places were used not only for transportation and work purposes but also as a means of trade. Many tradesmen specialized in horse rearing business. Horses were one of the sources of income and naturally, the question arose whether to establish zakat on horses. Another initiative came from the tradesmen themselves willing to pay zakat on their horse businesses. First, 'Umar was reluctant to add horses as animals which are included to pay zakat, but finally realizing that during the Prophet's (S.A.W.) time horses were only seen as transportation mode and after he found out about horse being source of income he agreed to add the horse as a zakatable animal. In the condition that horses were traded article, it was agreed that in this case income on a horse is liable to pay zakat. Muhamad cited the following hadith where it states that "We levy zakat on forty sheep, and we don't levy on these valuable horses. 'Umar then instructed Ya'la that he should charge zakat on horses

\footnotetext{
15 Surah al-Mujadila 58:13

${ }^{16}$ Muhamad A.A. (1993). Zakat and Rural development in Malaysia. Berita Publishing, Kuala Lumpur, Malaysia. See p.74
}

\footnotetext{
${ }^{11}$ Muhamad A.A. (1993). Zakat and Rural development in Malaysia. Berita Publishing, Kuala

Lumpur, Malaysia. P. 38

12 Ibid. See p. 39

${ }^{13}$ Ibid. See p.39

${ }^{14}$ Ibid. See p. 41
} 
at the rate of one dinar per horse"., 17 One new position of the zakat collector was established during the second khalifah time namely, 'ashir (tax collector). Siddiqi explains that "He collected prescribed zakat rates from the tradesmen. They were both instructed to collect jizya (poll tax) from non-Muslims and zakat on trade articles from eligible Muslims."18 Another development during 'Umar was regarding agricultural produce. He included peas, olives and lentils as zakatable items. 'Umar also brought innovations in the administrative side, such as:

a. Condition of the animals that are chosen as zakat performance should be of average quality.

b. Postponement of the zakat collection in the year of al-Ramada (drought) for a year, which undoubtedly was intended to minimize hardships on the people.

During the Khalifah 'Uthman ibn Affan's time, there were no changes in the zakat law and only questions regarding the zakat on the debtors raised. Questions such as does the debtor have to deduct the debt from his zakat calculation, or another issue was, should the person who has given a loan to consider it as his wealth or temporarily exclude a loaned amount from his zakat calculation. Most probably, to avoid such complications in the calculation of zakat, 'Uthman adopted the practice of reminding people to pay their debts prior to the zakat been collected. However, this method was not efficient enough and the solution for this issue awaited to be resolved. Regarding the debts - it was agreed that the debtor must exclude the amount of money he owes and calculate only property that are clear from any debts. Another issue arose when someone has given a loan to a person, should he include the given amount in the nisab calculation or wait until his loan been returned? There was such a case attributed to 'Umar. Muhamad writes that "It was reported that at the time of zakat collection, he charged merchants zakat on their assets which were hadir (present in their possession) and ghaib (assets belong to them but not available at the time). 'Ali was reported to hold a different view. He was inclined to charge zakat after the recovery of the loan. 'Uthman's solution was that if the creditor was able to recover his loan at the time of zakat collection but was reluctant to do so, he would then be charged

\footnotetext{
${ }^{17}$ Cited San'ani, op.cit. Vol. 4, pp35-36. Muhamad A.A. (1993). Zakat and Rural development in Malaysia. Berita Publishing, Kuala Lumpur, Malaysia. P.44

${ }^{18}$ Siddiqi M. A. S, (1983). Early development of Zakat law and Ijtihad. Karachi, Pakistan. see p. 94
}

zakat on his entire property, including his credits." 19 During the five-year rule of the fourth Khalifah 'Ali ibn Abi Talib, as Muhamad mentions, "There were no considerable amendments or changes, except that he excluded al hawamil wa al 'awamil (literally translated as beasts of burden or animals employed in work)" 20 in the zakat payment. There are a few possibilities why 'Ali came to this ijtihad. The first possibility is that according to the injunction from the Qur'an, zakat was levied on surplus wealth and only after essential personal needs are satisfied. Thus, it is quite possible that in interpreting and applying the same principle, 'Ali in his time exempted the above animals from zakat, considering them as essential for the peasants. The second possibility is related to the first one in a way that peasants used the above mentioned animals to work on the lands, helping to grow their agricultural produce and in this aspect, these animals were part of the established zakat on agricultural products.

\section{BIBLIOGRAPHY}

1. Ganiyev, Avazbek () "INSTITUTION OF ZAKAT IN COLONIAL MALAYSIA," The Light of Islam: Vol. 2020 : Iss. 1 , Article 2.

2. Malik b. Anas, Al-Muwatta' (version of Al-Shaybani)

3. Muhamad A. A. (1993). Zakat and rural development in Malaysia. Berita Publishing SDN BHD. Kuala Lumpur, Malaysia.

4. Powell R. (2010). Zakat: Drawing Insights for Legal Theory and Economic Policy from Islamic Jurisprudence. 7 PITT. TAX REV. 43.

5. Siddiqi M. A. S. (1983) Early Development of the Zakat Law and Ijtihad. First edition. Islamic research Academy, Karachi, Pakistan

6. Sunan Abu Dawud, Vol. 2

\footnotetext{
${ }^{19}$ Muhamad A.A. (1993). Zakat and Rural development in Malaysia. Berita Publishing, Kuala Lumpur, Malaysia. See p.47

${ }^{20}$ Ibid, see p. 47
} 